\title{
Má kona fæða ein?
}

Fyrir skömmu birtist viðtal við unga konu í Fréttablaðinu par sem hún lýsti fæðingu yngri dóttur sinnar. Um var að ræða ósköp fallega lýsingu á fæðingu en pað óvenjulega var að hún ákvað að eiga barnið heima án nokkurrar aðkomu fagfólks. Henni til stuðnings var barnsfaðirinn og allt gekk hratt og eðlilega fyrir sig og fylgdu viðtalinu fallegar myndir af fjölskyldunni.

Lesendur voru ekki lengi að bregðast við á netmiðlunum og í samtölum sín á milli. Eins og oft pegar fæðingar verða að umræðuefni voru skoðanir fólks mjög skiptar, allt frá pví að fólk hefði á orði að petta hlyti að vera ólöglegt yfir í að petta væri birtingarmynd hins algjöra kvenfrelsis.

Ekki er gott að átta sig á pví hve algengt pað er að konur velji að fæða börn án aðstoðar fagmanna, engin áreiðanleg skráning er til í heiminum. Hérlendis er petta sennilega afar fátítt. Flestar konur myndu fyllast skelfingu ef pær ættu ekki kost á fæðingarhjálp. Fyrrum pótti illbýlt á svæðum par sem ekki var hægt að ná í aðstoð fyrir konur í barnsnauð. pegar konur hafna fæðingarhjálp í okkar nútímasamfélagi liggur stundum erfið fæðingarreynsla að baki, stundum hið gagnstæða, en sammerkt er sannfæring um getu eigin líkama til að ráða við fæðinguna án truflana og inngripa og löngun til að stýra aðstæðum. Við megum ekki gleyma pví að punguð kona hefur jafnmikinn rétt og aðrir til að hafna meðferð svo framarlega sem hún er ekki haldin andlegum veikindum sem gætu skert getu hennar til að taka ákvarðanir um líf og heilsu.

Ef okkur finnst petta fráleit hugmynd ættum við frekar að horfa inn á við og spyrja okkur að pví hvers vegna konur vilji ekki piggja pá aðstoð sem við teljum nauðsynlega. Er eitthvað við framkomu okkar eða pær aðstæður sem við bjóðum konum að fæða börn sín í sem gæti verið fráhrindandi? Sumum konum finnst tæknileg sjúkrastofa með öllum öryggisbúnaði mjög aðlaðandi kostur meðan aðrar hræðast slíkar aðstæður og vilja heimilislegt umhverfi með ró og næði. Enn aðrar finna mesta öryggið á eigin heimili.

Rétt eins og bændur vilja vaka yfir ánum sínum í sauðburði til að vera tilbúnir að grípa inn í á réttu augnabliki vita peir að ærnar purfa ró og næði til að bera og óparfa truflanir geta leitt til ýmiss konar erfiðleika. Pó að einhverjum kunni að pykja pað óviðeigandi að bera konur saman við kindur erum við prátt fyrir allt dýrategund og pað er ýmislegt í pví frumstæða ferli sem fæðing er sem vert er að huga að. Ef við tökum ekki tillit til parfa fæðandi kvenna fyrir næði og stjórn á aðstæðum eigum viðá hættu að pær hrekjist frá okkur í aðstæður sem tryggja síður öryggi móður og barns. Vegna óvissu um skráningu er erfitt að svara pví með nákvæmni hve áhættusamt sé að fæða án aðstoðar. Рað má áætla að kona sem hefur sótt mæðravernd, hefur fætt eðlilega áður, er ung og hraust eigi mjög góðar líkur á pví að fæða án nokkurra inngripa eða alvarlegra fylgikvilla.

pær rannsóknir sem hafa birst um heimafæðingar benda til pess að útkoma fæðinga pessa hóps sé síst verri en peirra sem velja að fæða á sjúkrahúsi. Pessar rannsóknir ganga pó út frá pví að til staðar séu vel menntaðar ljósmæður sem fylgist með líðan barns og móður. Fylgikvillar fæðinga sjást ekki alltaf fyrir en fagfólk pekkir viðvörunarmerkin og getur brugðist tímanlega við og pó að alvarlegar bráðaaðstæður í fæðingum séu sjaldgæfar er nokkuð ljóst að pað getur skipt sköpum að fagfólk sé til staðar til að ekki hljótist skaði af.

Við álítum að fæðingarhjálp hérlendis sé með pví besta sem gerist í heiminum, útkoma mæðra og nýbura styður pað. Раð er samt ekki alltaf pannig að upplifun kvennanna sé jafn frábær og spilar auðvitað margt par inn í. Pó við höfum vel menntað fagfólk sem vinnur af hugsjón má eflaust gera betur, bæði hvað varðar undirbúning fæðinga og aðstöðu kvenna og fjölskyldna peirra. Við purfum líka alltaf að minna okkur á að umgangast fæðandi konur af virðingu og tillitssemi. Við sem vinnum á Landspítala, par sem 75\% fæðinga á landinu fara fram, vitum að plássið er alltof lítið og ekki hannað fyrir nútímakröfur um fæðingadeildir. Aðstaðan leyfir ekki pað næði sem er nauðsynlegt né pá hreyfingu sem væri æskileg fyrir fæðandi konur.

Óskandi væri að við gætum bæði tryggt öryggi sem best en á sama tíma komið til móts við mismunandi parfir fæðandi kvenna með bættri aðstöðu og viðmóti pannig að engri konu finnist hún purfa að ganga í gegnum fæðingu ein og óstudd.

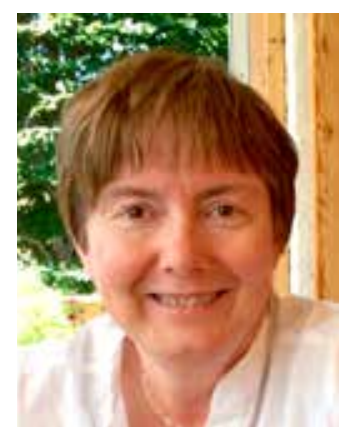

\section{Hulda Hjartardóttir}

yfirlæknir fæðingateymis Landspítala

huldahj@simnet.is

\section{Unassisted birth?}

Hulda Hjartardóttir, MD, FRCOG, Clinical Director of Obstetrics, Landspitali University Hospital, Reykjavík, Iceland.

DOI: 10.17992/lbl.2019.09.244 